\title{
PRELIMINARY DESCRIPTION OF NEW ISOPHYA (ORTHOPTERA: TETTIGONIOIDEA: PHANEROPTERIDAE) FROM SERBIA WITH REMARKS ON SOME KNOWN SPECIES
}

\author{
Dragan Pavićević \\ Institute for Nature Conservation of Serbia, Dr Ivana Ribara 91, 11070 Belgrade, dragan.pavicevic@zzps.rs
}

\begin{abstract}
Out of over 45 species of the genus Isophya in Europe, six of them have been recorded in Serbia thus far (Adamović, 1975; Pavićević et al., 2014b). Of these six species, two have been described from Serbia - Isophya modestior Brunner von Wattenwyl, 1882 (Niš - Bela Palanka) and Isophya obtusa Brunner von Wattenwyl, 1882 (Stara Planina Mt. - Tri Čuke). The species Isophya miksici Peshev, 1985 recorded at the Beljanica Mt. in eastern Serbia is new for the fauna of Serbia. This paper presents the preliminary descriptions of three new taxa, Isophya radmilae sp. n. from Radan Mt., Isophya pancici sp. n. from Tara and Zlatibor Mts. and Isophya clara orientalis ssp. n. from Belgrade (Miljakovac and Stepin Lug). The morphology of the new taxa has been analyzed with an overview of the relevant sketches and scans of stridulatory files of males.
\end{abstract}

Key words: Phaneropteridae, Isophya, new taxa, new faunistic data, Serbia.

\section{INTRODUCTION}

With 45 species present in Europe, the genus Isophya Brunner von Wattenwyl, 1878 is the second most numerous genus of the family Phaneropteridae (Heller et al, 1998). Due to the great morphological similarity among species, it can be said that the genus Isophya is, from the taxonomic point of view, very difficult and problematic. This genus has thus far been represented by 6 species in Serbia (Adamović, 1975; Pavićević et al., 2014b). First of them, Isophya speciosa (Frivaldszky, 1867) is a subendemic species of the Balkan Peninsula and it is most widespread in Serbia. The second one, Isophya modestior Brunner von Wattenwyl, 1882 was described from Serbia based on the specimens collected in forest clearings between
Извод: Од преко 45 врста рода Isophya у Европи, у Србији је досад било познато шест (Adamović, 1975; Pavićević et al., 2014b). Од тих шест врста две су описане из Србије, Isophya modestior Brunner von Wattenwyl, 1882 (Ниш - Бела Паланка) и Isophya obtusa Brunner von Wattenwyl, 1882 (Стара планина - Три Чуке). Као нова врста за фауну Србије наводи се Isophya miksici Peshev, 1985 пронађена на планини Бељаници у источној Србији. У раду су дати прелиминарни описи три нова таксона, Isophya radmilae sp. n. са планине Радан, Isophya pancici sp. n. са планине Таре и Златибора и Isophya clara orientalis ssp. n. из Београда (Миљаковац и Степин Луг). Анализирана је морфологија нових таксона уз приказ релевантних цртежа и фотографија стридулационих жилица мужјака.

Клучине речи: Phaneropteridae, Isophya, нови таксони, нови фаунистички подаци, Србија.

Niš and Bela Palanka (Brunner von Wattenwyl, 1882) and it is a subendemic species of the Balkan Peninsula relatively common in eastern and central Serbia. The third one, Isophya obtusa Brunner von Wattenwyl, 1882 was described on the Stara Planina Mountain (Tri Cuke) based on the specimens collected by the famous Serbian botanist and orthopterologist Josif Pančić who was an associate and friend of the then leading Swiss expert on orthoptera in Europe, Carl Brunner von Wattenwyl who described that species. Exactly 133 years after the description of the aforementioned species, the author again found this species at two sites on the Stara Planina Mountain, Vražja Glava (1860 $\mathrm{m})$ and Stražna Čuka $(1750 \mathrm{~m})$ which are very close 
to the type site of Tri Čuke (1937 m). This species is also known from central and western Bulgaria (Stara, Lyulin, Vitosha and Plana Mountains) (Chobanov, D. P. et al. 2013). The fourth one, Isophya clara Ingrisch \& Pavićević, 2010, was described based on the specimens from Montenegro and Serbia (Ingrisch \& Pavićević, 2010) and it is relatively common at hilly areas and mountains of western Serbia (Pavićević et al., 2014b). The fifth one, Isophya bureschi Peshev, 1959, was described from Bulgaria (the central and southwestern Bulgaria), and has been found in Serbia as well, in mesophilic meadows near Vlasina lake (Pavićević et al., 2014b). The sixth one, Isophya costata Brunner von Wattenwyl, 1878, is an endemic species of the Pannonian Basin and has recently been discovered in Selevenj Heath and Subotica Sands (Szövényi \& Szekeres, 2011; Pavićević \& et al., 2014b). The author found the species Isophya miksici Peshev, 1985 at Beljanica Mountain in eastern Serbia which was described from Bulgaria and known only from there. This species is new for the fauna of Serbia.

During the research on the Orthoptera fauna of Serbia in 2014 and 2015, two new species from the genus Isophya were discovered. The first one was found in a mesophilic meadow at $1250 \mathrm{~m}$ a.s.l. on the Radan Mountain (above the site Đavolja Varoš) in southern Serbia. The second one was found in clearings in coniferous forests on two mountains, Tara (the village of Račanska Šljivovica at $1200 \mathrm{~m}$ ) and Zlatibor (Partizanske Vode at $1050 \mathrm{~m}$ ) in western Serbia. One new subspecies of the aforementioned genus was based on specimens previously collected at two sites in Belgrade, Miljakovac and Stepin Lug. The descriptions of the three new taxa are presented in this paper.

\section{MATERIALS AND METHODS}

During the orthopterological research of the Radan, Tara and Zlatibor Mountains in 2014 and 2015, the author collected very interesting material from which two new cricket species from the genus Isophya stand out as the most important. The material was collected manually and dry pinned at the laboratory of the Institute for Nature Conservation of Serbia. Scans of stridulatory files of males were captured on an electronic microscope (JEOL JSM $6460 \mathrm{LV}$ ) at the University Centre for Electron Microscopy Novi Sad. The following references were used for the determination of species: Ramme (1951), Harz (1969), Heller et al. (2004), Ingrisch \& Pavićević (2010) and Chobanov D. P. et al. (2013).

\section{ABBREVIATIONS}

INCS - Collection of the Institute for Nature Conservations of Serbia, Belgrade, Serbia.

CDPV - Private Collection of Dragan Pavićević, Belgrade, Serbia.

\section{Isophya radmilae sp. $\mathbf{n}$.}

Holotype (male): Serbia: Radan Mt., 1250 m., 05.07.2014, leg. D. Pavićević (INCS).

Paratypes: Serbia: Radan Mt.: 9 $\hat{,}, 12$ ㅇ, same data as in holotype, leg. D. Pavićević; $4 \hat{\partial}, 3 \propto$ do., 05.09.2014, leg. D. Pavićević (INCS, CDPV).

Type site: Serbia, Radan Mt., mesophilic meadow at an altitude of $1250 \mathrm{~m}$.

Diagnosis: The new species is similar to $I$. modestior Brunner von Wattenwyl, 1882. It differs from I. modestior by a smaller body size, shorter pronotum and tegmen, on average more teeth on stridulatory file. Cerci of male are slender. The ovipositor is shorter, moderately upcurved. The male song consists of syllables with several after-clicks.

Description: A medium-sized species with males measuring $19-21 \mathrm{~mm}$, and females measuring 19 $22 \mathrm{~mm}$. Fastigium verticis $(0.37-0.41)$ shallowly to deeply furrowed above, narrower than scapus (0.74 $-0.75)$.

Male: (Fig. 1. A; Fig. 2. A, C, D; Fig. 3. A, B). Pronotum is saddle-like, $4.22-4.51 \mathrm{~mm}$ long, constricted at midlength in the transverse sulcus area, with posterior area slightly raised. Tegmina shorter than pronotum, $3.71-4.10 \mathrm{~mm}$. Stridulatory file with numerous teeth, 210 - 231. Epiproct transverse, apicolateral angles rounded. Cerci gradually narrowing toward apex, curved in apical third; apex with a strong median tooth. Subgenital plate narrowing before apex, incised in middle. Postfemur $17.5-18 \mathrm{~mm}$.

Female: (Fig. 1. B; Fig. 2. B, E, F). Pronotum 4.89 - $5.21 \mathrm{~mm}$, longer than tegmina, slightly widening posteriorly, lateral and dorsal margins substraight. Tegmina $1.69-1.81 \mathrm{~mm}$. Cerci conical, apex subacute to subobtuse. Subgenital plate small, transversetriangular. Ovipositor $12-12.5 \mathrm{~mm}$, sabre-shaped, moderately upcurved, apex dentate. Postfemur 17.5 $-18 \mathrm{~mm}$.

Coloration: Green with poorly pronounced brownish dots. Two white lateral bands on vertex, discus of pronotum and ventral margins of pronotum. Pronotum with two red stripes medial of the white band. Tegmina of male with a brown spot on discus between Media and Cubitus 2. Cerci yellowish.

The male song consist of syllables with five to six after-clicks which brings this new species close to 
Preliminary description of New Isophya (Orthoptera: Tettigonioidea: Phaneropteridae) from Serbia with remarks on some known species
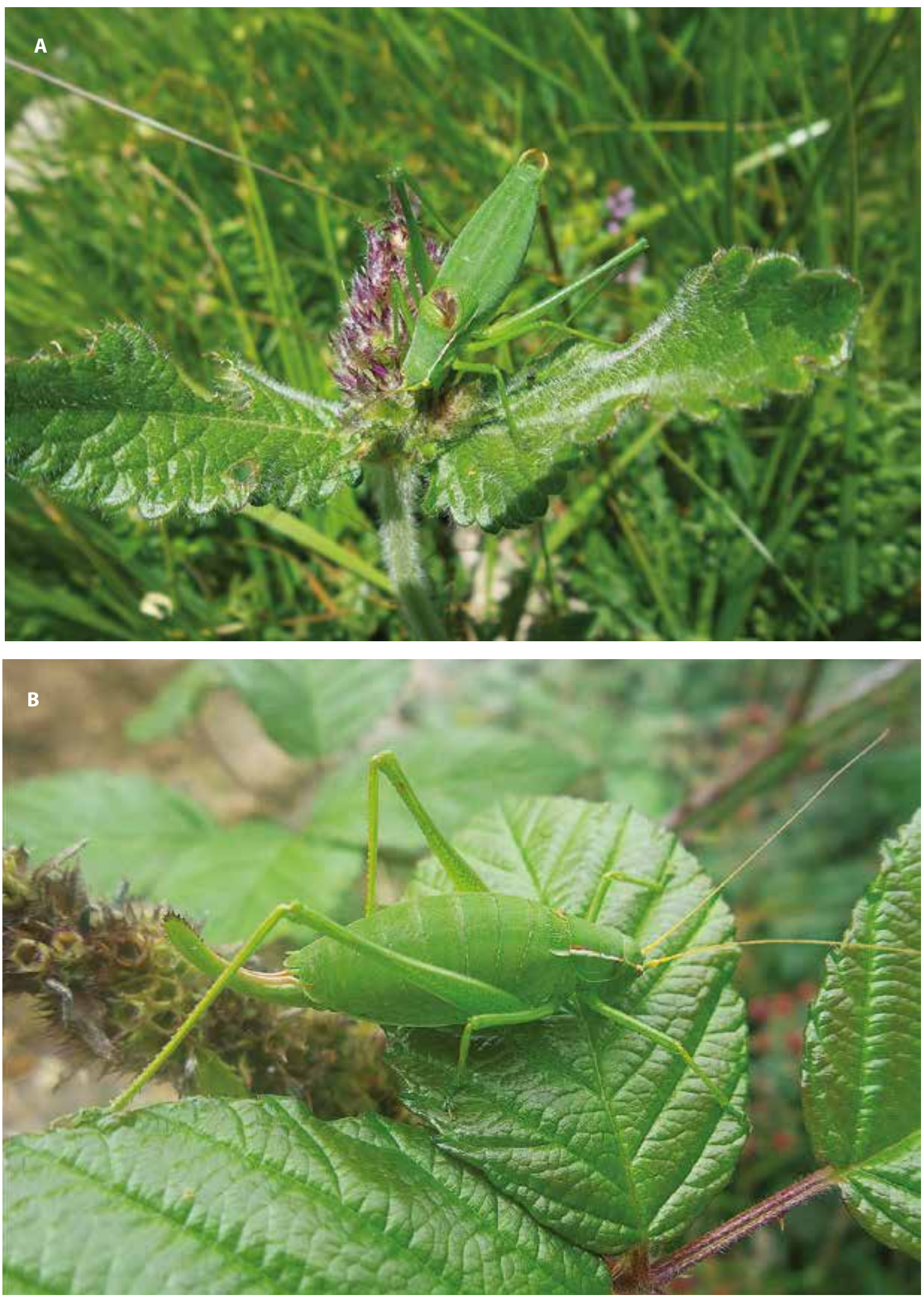

Figure 1. Isophya radmilae sp. n.: A, male habitus, B, female habitus, Photo: D. Vukićević Слика 1. Isophya radmilae sp. п.: A, хабитус мужјака, B, хабитус женке, Фото: Д. Вукићевић 


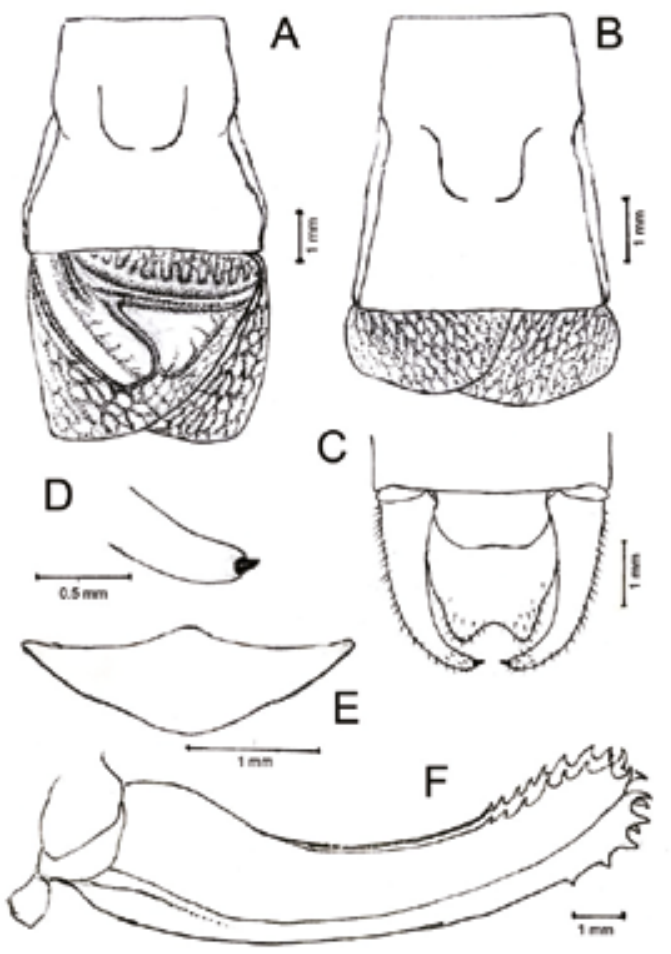

Figure 2. Isophya radmilae sp. n. male ( $A, C, D)$ and female (B, E, F). $A, B$, pronotum and tegmina, viewed dorsally; $C$, abdominal apex of male, viewed dorsally; $D$, apex of left male cercus; $F$, subgenital plate of female, viewed ventrally; $G$, ovipositor.

Слика 2. Isophya radmilae sp. n. мужјак $(A, C, D)$ и женка (B, E, F). A, B, пронотум и тегмени, гледано дорзално; $C$, абдоминални врх мужјака, гледано дорзално; D, врх левог иерка мужјака; $F$, субгенитална плоча женке, гледано вентрално; $G$, легалица.

the complex "Isophya andreevae" consisting of two species, Isophya tosevski Pavićević, 1983 and Isophya andreevae Peshev, 1981 (Chobanov et al, 2013). The morphology is different from two mentioned species.

Etymology: Isophya radmilae sp. n., is dedicated to the memory of my late wife, Radmila Mladenović which was my great support in life and scientific work.

Habitat and distribution: Mesophilic meadows with dense grass and herbaceous vegetation at an altitude of $1250 \mathrm{~m}$. Only known from locus typicus, the Radan Mt. in southern Serbia.

Conservation status: Isophya radmilae sp. $\mathrm{n}$. is only known from the Radan Mt. It has been found only at one site, thus can be considered endangered. The Government of Serbia has recently issued the Decree on the designation of the Nature Park "Radan" which has been classified as protected area of the category I of the international and national, or outstanding importance ("Official Gazette of RS" No. 91/2017).

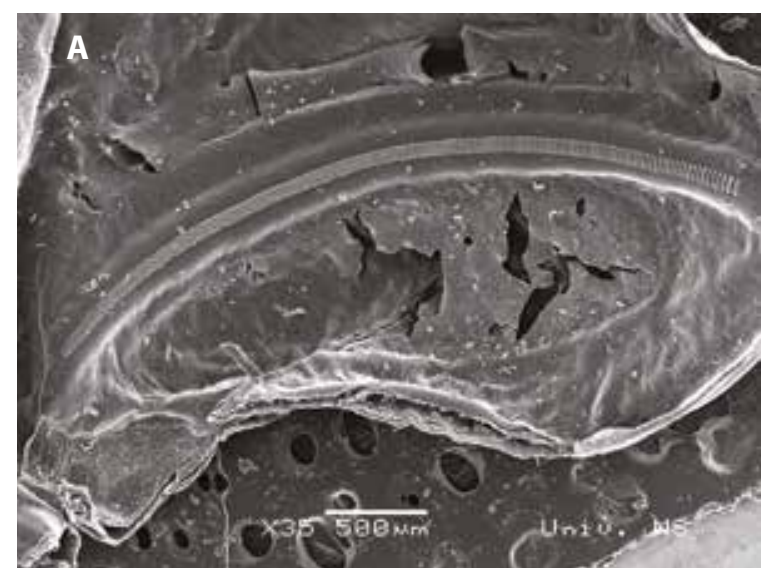

B

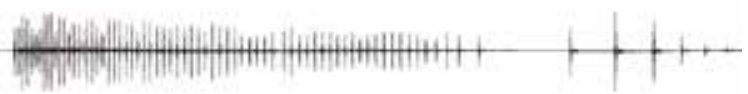

Figure 3. Isophya radmilae sp. $n$. A, a scan of the stridulatory file of male using an electronic microscope; $B$, oscillogram of single syllable of male.

Слика 3. Isophya radmilae sp. n. A, стридулациона жилица мужјака скенирана електронским микроскопом; В, осиилограм једног слога мужјака.

This form of protection largely guarantees the survival of habitats of this rare species and the survival of species itself.

\section{Isophya pancici sp. $\mathrm{n}$.}

Holotype (male): Serbia, Tara Mt., Račanska Šljivovica, $1200 \mathrm{~m}, 14.07 .2015$, leg. D. Pavićević (INCS).

Paratypes: Serbia: $5 \hat{\sigma}, 11 \stackrel{+}{\circ}$, same data as in holotype, leg. D. Pavićević.; 3 đ, 2 q, Tara Mt. Spajići, 1200 m., 14.07.2015, leg. D. Pavićević; 3 ठૈ, 5 ㅇ, Zlatibor Mt., Partizanske Vode, 1,200 m, leg. D. Pavićević (INCS, CDPV).

Type site. Serbia, Tara Mt.- Šljivovica, clearings in coniferous forests at an altitude of $1200 \mathrm{~m}$.

Diagnosis: The new species is similar to $I$. modestior Brunner von Wattenwyl, 1882. It differs 
Preliminary description of New Isophya (Orthoptera: Tettigonioidea: Phaneropteridae) from Serbia with remarks on some known species

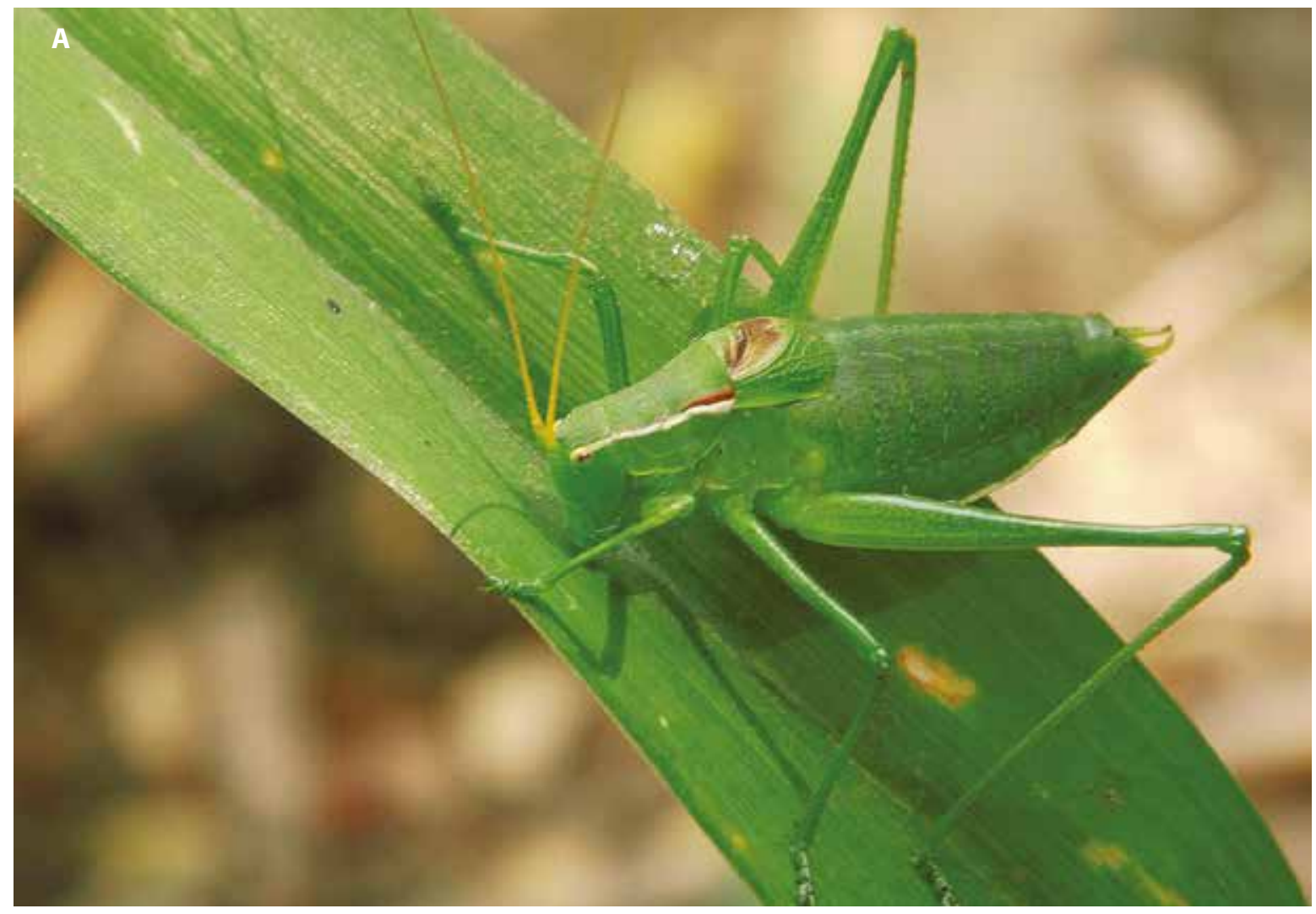

B

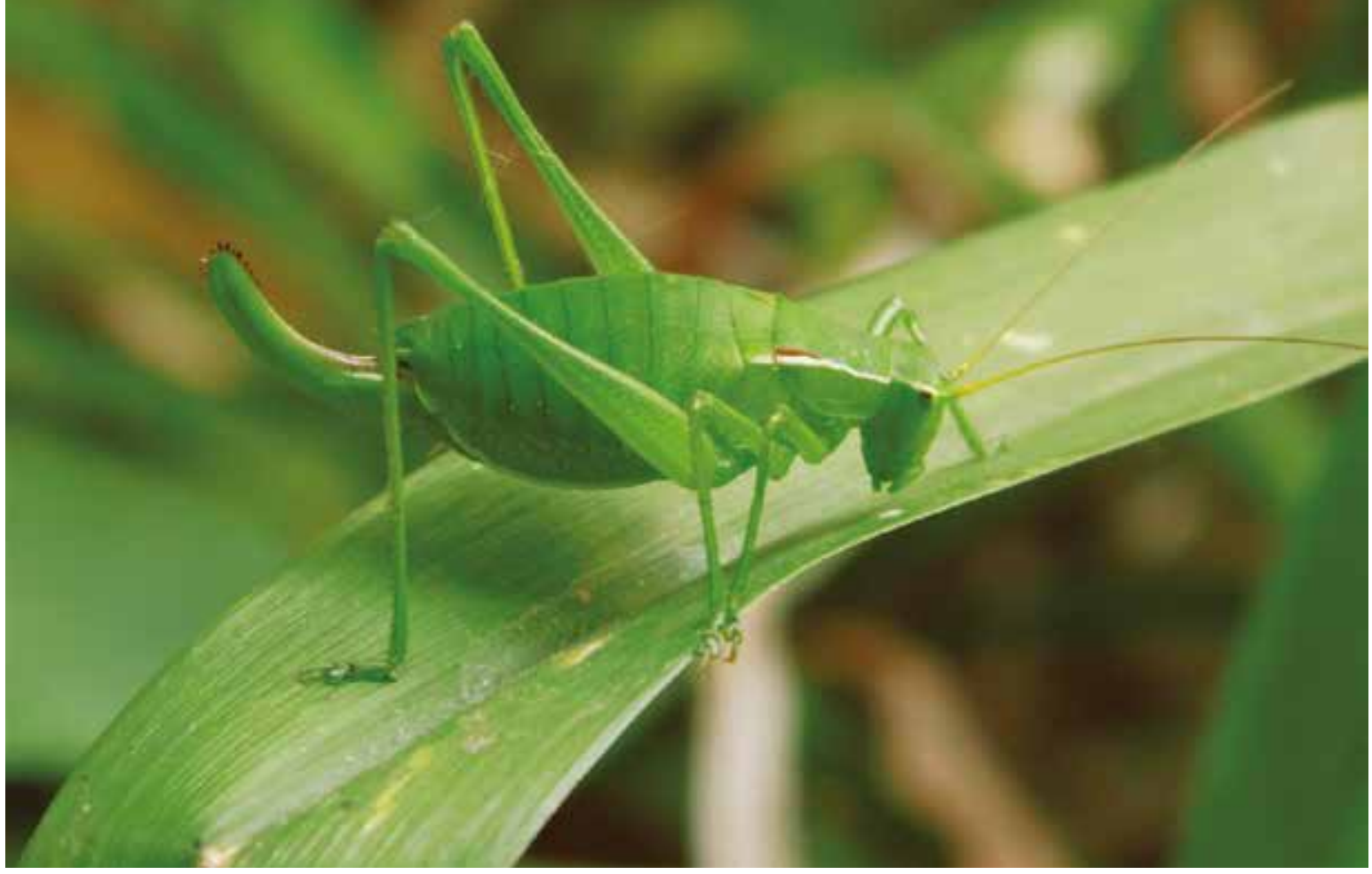

Figure 4. Isophya pancici sp. n.: A, male habitus, B, female habitus, Photo: D. Vukićević Слика 4. Isophya pancici sp. п.: A, хабитус мужјака, В, хабитус женке, Фото: Д. Вукићевић 


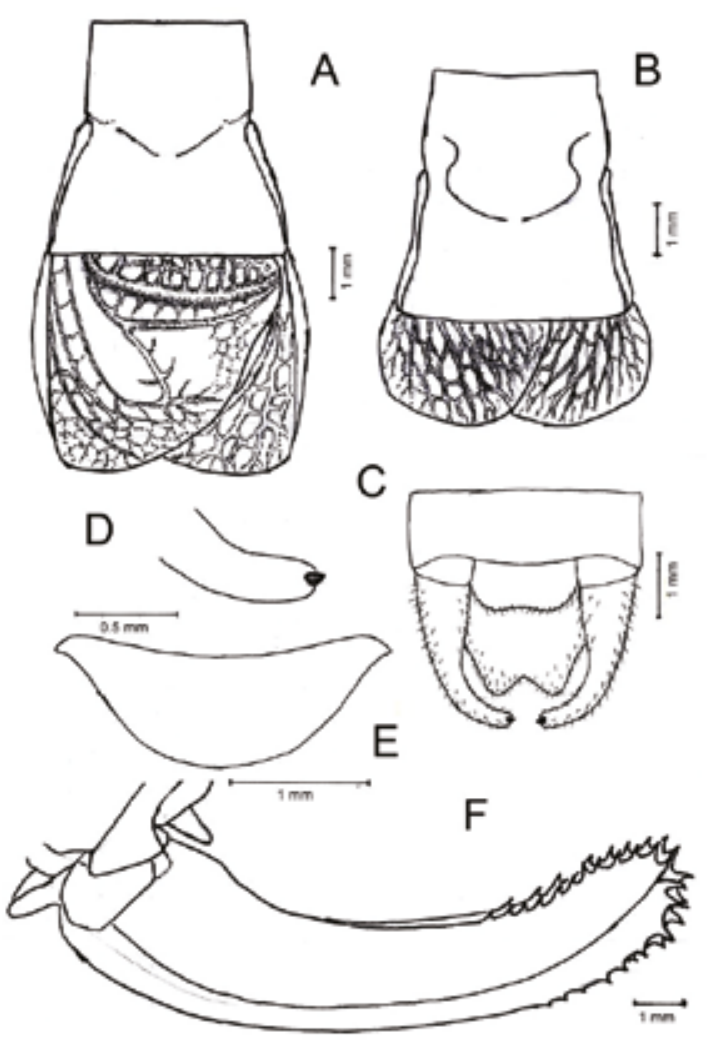

Figure 5. Isophya pancici sp. n. male $(A, C, D)$ and female $(B, E, F)$. $A, B$, pronotum and tegmina, viewed dorsally; $C$, abdominal apex of male, viewed dorsally; $D$, apex of left male cercus; $F$, subgenital plate of female, viewed ventrally; $G$, ovipositor.

Слика 5. Isophya pancici sp. n. мужјак $(A, C, D)$ и женка (B, E, F). $A, B$, пронотум и тегмени, гледано дорзално; $C$, абдоминални врх мужјака, гледано дорзално; $D$, врх левог иерка мужјака; $F$, субгенитална плоча женке, гледано вентрално; G, легалица

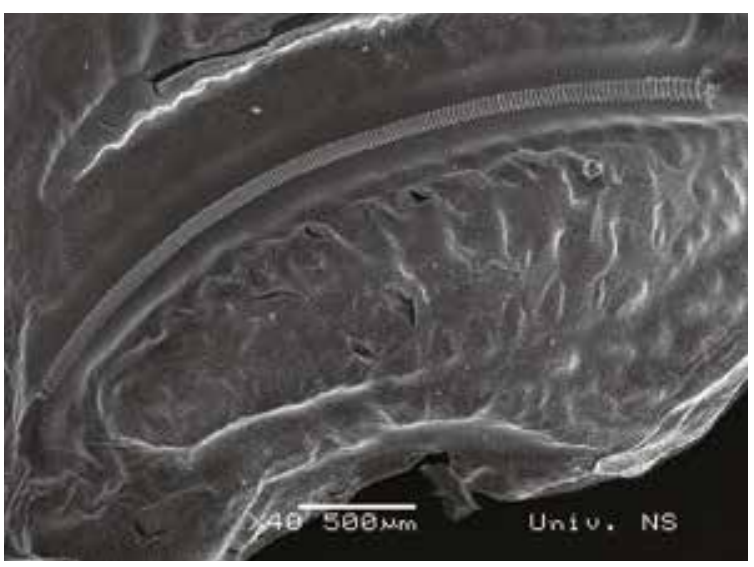

Figure 6. Isophya pancici sp. n., a scan of the stridulatory file of male using an electronic microscope.

Слика 6. Isophya pancici sp. п., стридулациона жилица мужјака скенирана електронским микроскопом from I. modestior by a smaller body size, shorter pronotum but longer tegmen and different apex of cerci. Ovipositor is shorter, moderately curved upside. The male song is unknown.

Description: A medium-sized species, males grow between $22-23 \mathrm{~mm}$, females between $22-24 \mathrm{~mm}$. Fastigium verticis $(0.31-0.35 \mathrm{~mm})$ shallowly to deeply furrowed above, narrower than scapus $(0.71-0.74)$.

Male: (Fig. 4A; Fig. 5A, C, D; Fig. 6) Pronotum 4.31- $4.41 \mathrm{~mm}$ long, saddle-shaped, with lateral carinae nearly parallel in prozone, broken at transverse sulcus, widen and divergent in metazone. Tegmina $4.41-4.52 \mathrm{~mm}$, almost equal or longer than pronotum. Stridulatory file with $174-190$ teeth. Eppiproct transverse, apico-lateral angles rounded. Cerci gradually narrowing toward apex, curved in apical third; apex obtuse, with a more dorsally implanted tooth. Subgenital plate narrowing before apex, incised in middle. Postfemur length $17.5-18 \mathrm{~mm}$.

Female: (Fig. 4B, Fig. 5B, E, F). Pronotum 4.6 $-4.8 \mathrm{~mm}$, weakly widening and raised posteriorly, lateral and dorsal margins substraight. Tegmina 1.7 - $2.4 \mathrm{~mm}$. Epiproct rounded to transversely rounded. Cerci conical, apex subacute to subobtuse. Subgenital plate small, transverse-triangular. Ovipositor 11.5 $12.5 \mathrm{~mm}$, sabre-shaped, moderately upcurved, apex dentate. Postfemur length $17.5-19 \mathrm{~mm}$.

Coloration: Green with light brownish dots. Two white lateral bands on vertex, discus of pronotum and ventral margins of pronotum. Pronotum with two red stripes medial of the white band. Tegmina of male with a brown spot on discus between Media and Cubitus 2. Cerci yellowish.

Etymology: Isophya pancici sp. n., is dedicated to the memory of the famous Serbian botanist and orthopterologist, Josif Pančić (1814 - 1888).

Habitat and distribution: Clearings in coniferous forests with dense grass and plants on the Tara and Zlatibor Mts., between $1050-1200 \mathrm{~m}$. Until now it has only been recorded on these two mountains.

Conservation status: Isophya pancici sp. n. has only been recorded on two mountains in southwestern Serbia, Tara and Zlatibor. It can be said that the prospects for survival of this species are very good because its habitats are for the most part located within the borders of the National Park "Tara" and the recently designated Nature Park "Zlatibor".

\section{Isophya clara orientalis ssp. $\mathbf{n}$.}

Holotype (male): Serbia: Belgrade - Miljakovac, 31.05.1978, leg. D. Pavićević (CDPV).

Paratypes:. Serbia: $4 \stackrel{\lambda}{\hat{}}, 5$ ㅇ, Belgrade-Miljakovac, freshmeadow, samedata asinholotype,leg.D.Pavićević.;

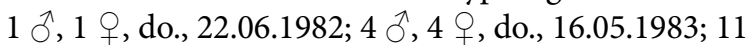

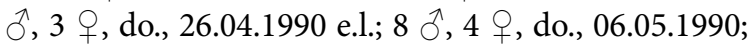

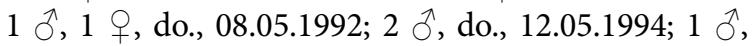
1 ㅇ, do., 29.05.1994; 2 ô, do., 02.07.1994; 1 ठै, do., 
Preliminary description of New Isophya (Orthoptera: Tettigonioidea: Phaneropteridae) from Serbia with remarks on some known species
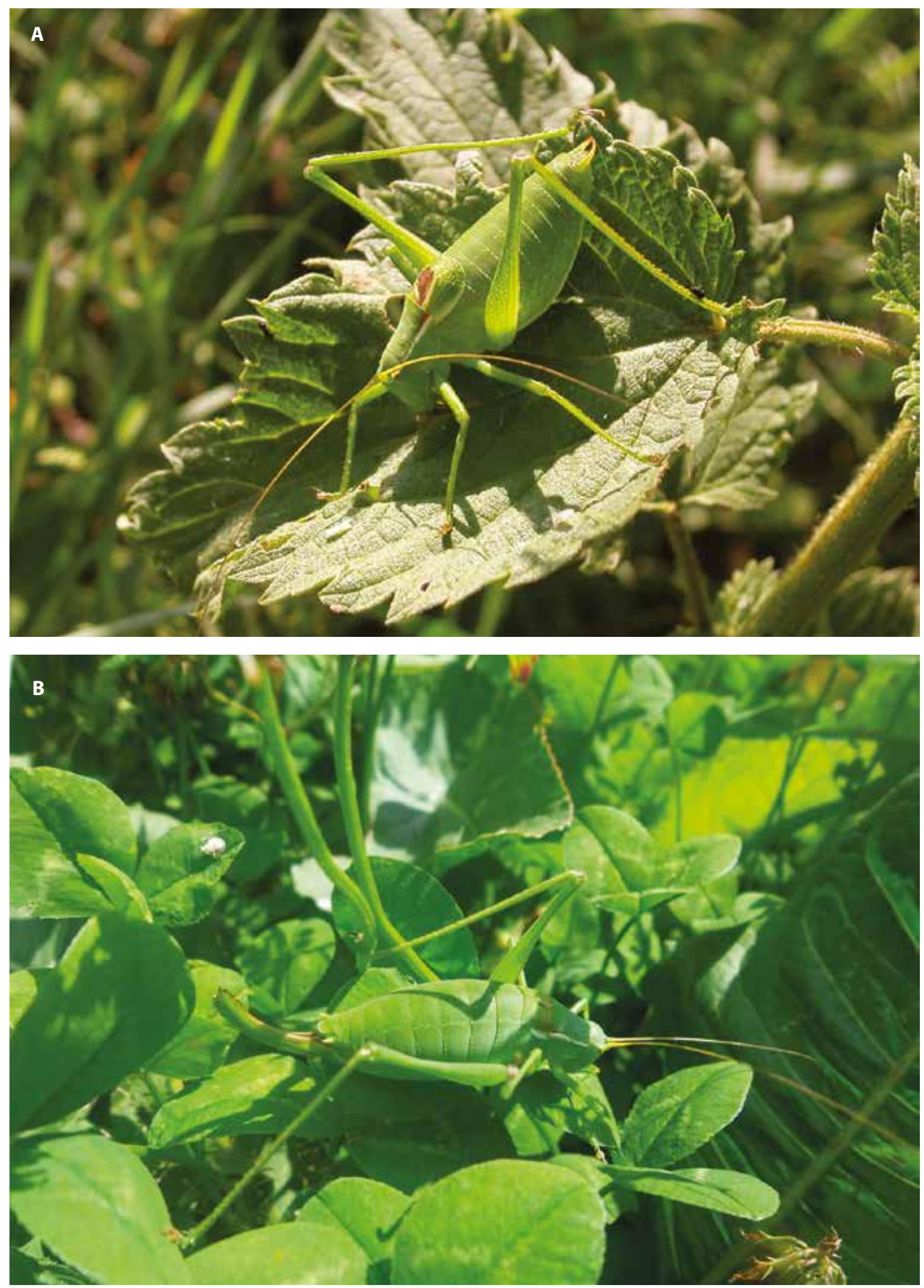

Figure 7. Isophya clara orientalis ssp. $n$. A, male habitus, B, female habitus, Photo: D. Vukićević Слика 7. Isophya clara orientalis ssp. n. A, хабитус мужјака, В, хабитус женке, Фото: Д. Вукићевић 


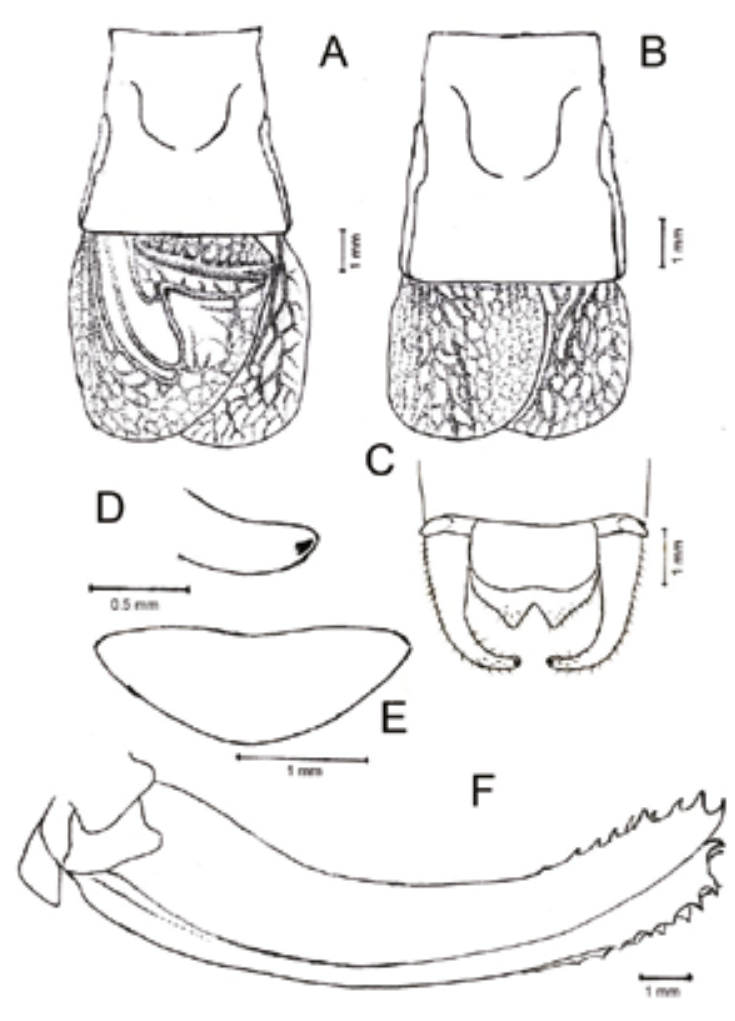

Figure 8. Isophya clara orientalis ssp. n. male $(A, C, D)$ and female $(B, E, F) . A, B$, pronotum and tegmina, viewed dorsally; $C$, abdominal apex of male, viewed dorsally; $D$, apex of left male cercus; $F$, subgenital plate of female, viewed ventrally; $G$, ovipositor.

Слика 8. Isophya clara orientalis ssp. n. мужјак $(A, C, D)$ и жен$\kappa a(B, E, F) . A, B$, пронотум и тегмени, гледано дорзално; $C$, абдоминални врх мужјака, гледано дорзално; D, врх левог иерка мужјака; F, субгенитална плоча женке, гледано вентрално; $G$, легалииа.

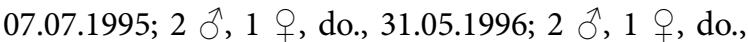
14.05.2007; 1 ठे, do., 20.06.2008; 1 ふे, do., 14.06.2009; $2 \hat{\jmath}, 1$, , do., 02.06.2015; $1 \hat{\jmath}$, do., 18.06.2015; $4 \hat{\jmath}, 4$ 9 , Belgrade - Stepin Lug, fresh meadow near a pond, 25.05.2007, leg. D. Pavićević (CDPV, INCS).

Type site: Serbia, Belgrade - Miljakovac, mesophilic meadow.

Diagnosis: The new subspecies is very similar to Isophya clara clara Ingrisch \& Pavićević, 2010 (Ingrisch \& Pavićević, 2010). I. clara orientalis ssp. n. differs from nominotypical subspecies, I. clara clara by, on average, smaller size and longer tegmen with blackish brown spot in male and with fewer teeth on the stridulatory files. Epiproct in male more subquadrate, apico-lateral angles rounded and slightly concave in between. Subgenital plate in male with triangular apical lobes smaller. Cerci of female subobtuse to obtuse. Subgenital plate of female transversely rounded. Oviposiotor shorter. The male stridulation is mono- syllabic with single, uninterrupted pulse series, same as in I. clara clara (Ingrisch \& Pavićević, 2010).

Description: A medium-sized to large species, males measure 19 - $25 \mathrm{~mm}$, females measure 19 $27 \mathrm{~mm}$. Fastigium verticis $(0.40-0.50)$, shallowly to deeply furrowed above, narrower than scapus (0.70 $0.80)$.

Male: (Fig. 7A; Fig. 8A, C, D). Pronotum 4.71 - 5.14 $\mathrm{mm}$ widening posteriorly, lateral margins sub-straight to weakly concave, dorsal margin from almost straight to slightly raised before posterior margin. Tegmina longer than pronotum, $4.80-5.10 \mathrm{~mm}$. Stridulatory file with 58-72 teeth of increasing size from base to internal margin of wing. Epiproct transverse, apico-lateral angles rounded. Cerci gradually narrowing towards apex, curved in apical third of circa; apex transversetruncate and with a minute tooth. Subgenital plate narrowing before apex; apex with two triangular lobes. Postfemur 18.5 - $19 \mathrm{~mm}$.

Female: (7B; Fig. 8B, E, F) Pronotum, 5.10 - 5.5 $\mathrm{mm}$ slightly widening posteriorly, lateral and dorsal margins substraight. Length of tegmina $2.50-3.10$ $\mathrm{mm}$. Epiproct rounded to transversely rounded. Cerci conical, apex subacute to subobtuse. Subgenital plate small, transverse-triangular. Ovipositor 12.5 - $13 \mathrm{~mm}$ sabre-shaped, slightly curved, apex dentate. Postfemur $20-23 \mathrm{~mm}$.

Coloration. Green with blackish brown dots. Two white lateral bands on vertex, discus of pronotum, and ventral margins of pronotum. Pronotum with two red stripes medial of the white band. Tegmina of male with a large medium blackish brown spot on discus between Media and Cubitus 2.

Etymology: The name of the new taxon comes from the distribution area which is the easternmost from the nominotypical subspecies, I. clara clara.

Habitat and distribution: Mesophilic meadows in lowland with dense high grass and plants close to creeks or ponds. Until now it has only been recorded at two sites in Belgrade, Miljakovac and Stepin Lug.

Conservation status: Isophya clara orientalis ssp. n. has only been recorded at two sites in Belgrade, Miljakovac and Stepin Lug. Both sites are not more than one hectare in size and belong to the same habitat type, mesophilic meadows with dense tall grassland and herbaceous vegetation. This taxon can be considered endangered, thus measures to protect its habitats in Belgrade should be taken as soon as possible.

Cricket species from the genus Isophya new for the fauna of Serbia has been discovered upon processing the material collected over previous years. 


\section{Isophya miksici Peshev, 1985}

This species has until now only been known from northwestern Bulgaria (Chobanov, D. P., et al., 2013). The author found this species on the Beljanica Mountain in eastern Serbia on July 23, 1997, at the site Govedarište $(750-800 \mathrm{~m})$, as well as on July 27 and 28,2001 , at the sites Đula $(750 \mathrm{~m})$ and Straža $(1240 \mathrm{~m})$. This species prefers mesophilic mountain meadows with dense grassland and herbaceous vegetation (Đula and Straža) but has also been found in forest clearings at the site Govedarište. This species belongs to the complex "Isophya modesta" which includes seven taxa from five species: I. clara, I. miksici, I. plevnensis, I. longicaudata adamovici, I. longicaudata longicaudata, I. modesta modesta and I. modesta rossica. The aforementioned species have a stridulatory file with 55 - 160 teeth. In the specimen I. miksici from Bulgaria, the stridulatory file contains between $65-88$ teeth, while the same specimen from the Beljanica Mt. has a stridulatory file with $66-70$ teeth. This species is a new and subendemic species for the fauna of Serbia.

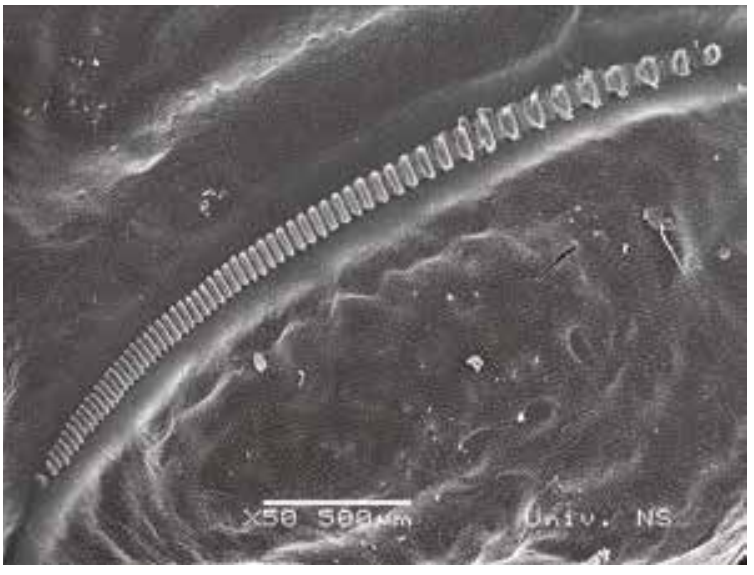

Figure 10. Isophya miksici, a scan of the stridulatory file of male using an electronic microscope.

Слика 10. Isophya miksici, стридулациона жилица мужјака скенирана електронским микроскопом.

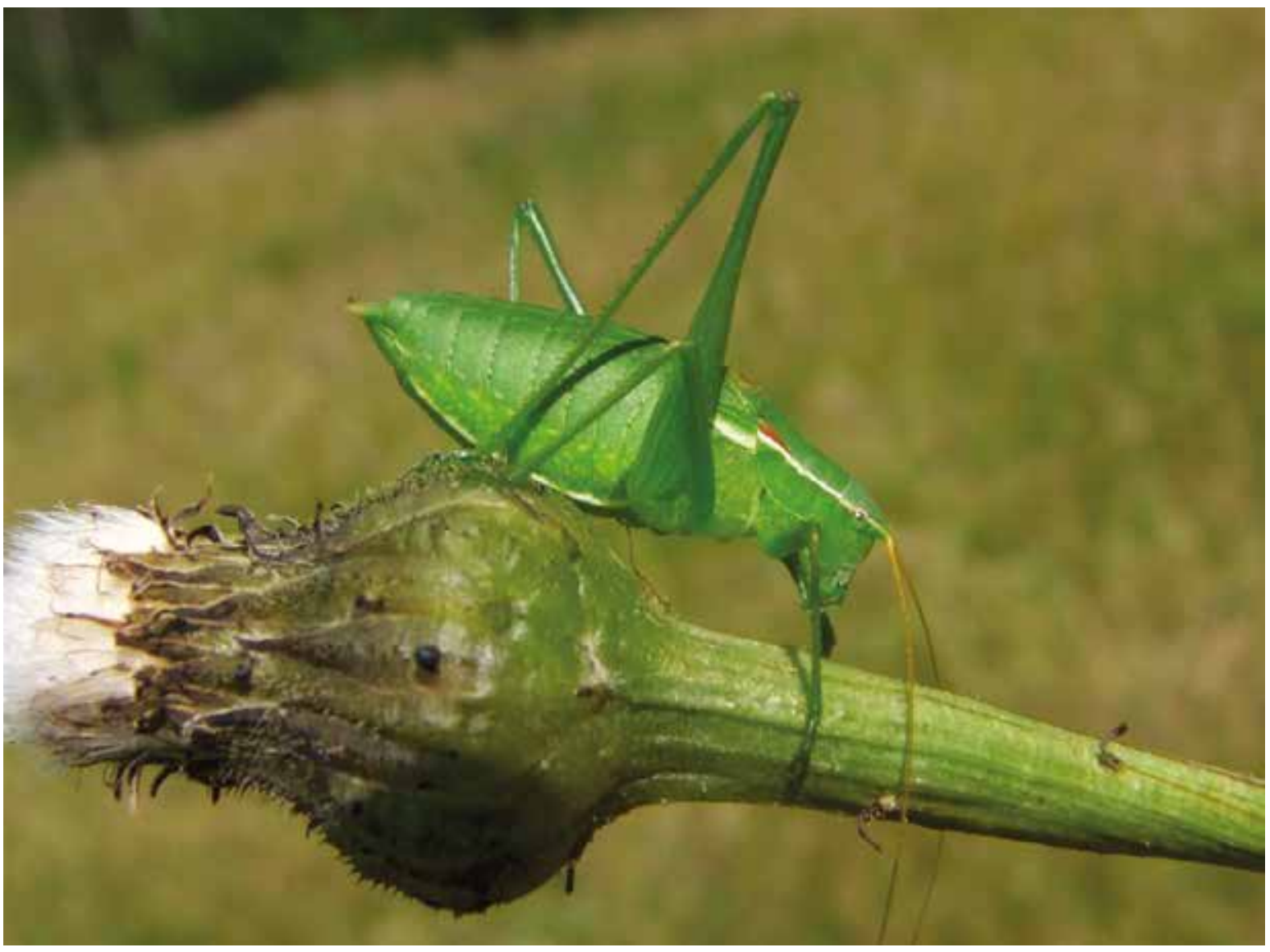

Figure 9. Isophya miksici: male habitus, Photo: D. Vukićević Слика 9. Isophya miksici: хабитус мужјака, Фото: Д. Вукићевић 


\section{DISCUSSION}

The representatives of the genus Isophya prefer mesophilic meadows with dense grassland and herbaceous vegetation, well-shaded edges of forests, mesophilic forest clearings, both in lowland and mountainous areas up to $2000 \mathrm{~m}$. Of species inhabiting Serbia, I. costata and I. clara orientalis are steppicolous species, while I. obtusa, I. bureschi, I. miksici, I. clara clara, as well as two new species I. radmilae and I.pancici are exclusively mountainous species. It can be said that the species I. speciosa tolerates various altitudes which is why it can be found both in lowlands and at an altitude of up to $2000 \mathrm{~m}$. The species I. modestior which, according to literature data, occurs at a large number of sites in Serbia deserves a separate mention. This species was described from Serbia (Brunner von Wattenwyl, 1882). The specimens were collected by the author himself, Brunner von Wattenwyl in forest clearings between Niš and Bela Palanka ("Ich fand diese Species in einer lichten Waldstelle zwischen Nisch und Ak Palanka in Serbien") and described in his monograph on European Orthoptera ("Prodromus der europäischen Orthopteren") which was published in 1882. In the same work, Brunner described a similar species, Isophya fusconotata, based on a specimen from the Rtanj and Suva Planina Mountains, and that species is not mentioned later on in his work "Additamenta zur Monographie der Phaneropteride" from 1891. Famous German orthopterologist Willy Ramme, in his book "Orthopterten von SüdostEuropa und Vorderasien" published in 1951 considers the species I. fusconotata to be a younger synonym of the species I. modestior. A more recent work by a group of authors (Heller et al., 2004) "The Isophya species of Central and Western Europe (Orthoptera: Tettigonioidea: Phaneropteridae)" states that the species Isophya modestior is "separated by a large gap without findings". They state that the type site, as well as some additional data on this species, is located in Serbia, Macedonia, western Bulgaria and Montenegro, while other data originate from Slovenia, Italy, Austria and Hungary. This group of authors did not examine the type specimen of the species I. modestior from the collection of the Natural History Museum in Vienna during the course of writing their work. They designated a male I. fusconotata from the Suva Planina Mountain as the lectotype of I. modestior described by Brunner and believed I. fusconotata to be a younger synonym of the species I. modestior (Heller et al. 2004). The author of the work had a chance to visit and orthopterologically research the area of Niš and Bela Palanka on several occasions in 2015 , and to find at several sites numerous species which unequivocally belong to the Brunner's species I. modestior, exactly 133 years after its description. The collected specimens morphologically fully correspond to the Brunner's description in 1882. The populations of this species inhabit steppe terrains and forest clearings in hilly areas in the valleys of Niš and Bela Palanka which have a humid continental climate, and partly sub-Mediterranean climate. The species was most numerous in the early and mid-June while it experienced a severe decline in numbers in mid-July. From the site Divna Gorica $(1,200 \mathrm{~m})$ at the Suva Planina Mountain which rises above the aforementioned valleys, the author collected only two specimens, a male and a female from the genus Isophya which are morphologically and phenologically different from the species I. modestior, however, that is not enough data for drawing any conclusions whether they belong to the same species or whether Brunner's I. fusconotata is, in fact, an actual species. In this work, the specimens collected at the very same sites where Brunner collected and described the species I. modestior were used for the morphological comparison with the new species. It can be said that the new species I. radmilae has an uncanny morphological resemblance to the species I. modestior, but also differs from it based on the aforementioned description, especially in terms of male song. Similarly, the other new species I. pancici has a morphological resemblance to the species I. modestior, but while the apical tooth of the cerci has a more dorsal position in the species I. pancici, the same tooth has a median position in the species I. modestior. Due to low vagility, great mutual morphological resemblance and dependence on a certain type of habitat of the representatives of the genus Isophya, the author expresses doubts about the possible existence of vast distribution ranges of certain species, including the species Isophya modestior. This position is supported by the fact that many new species of the aforementioned genera hardly recognizable at morphological level have been described, primarily with the help of bioacoustics and molecular genetics.

\section{ACKNOWLEDGMENTS}

The author would like to thank his colleagues from the Institute for Nature Conservation of Serbia, Dejan Vukićević, Slobodan Čvrkić and Živorad Nešić for helping him during field work. The author owes a special thanks to his colleagues Miloš Bokorov (Department of Biology and Ecology, Novi Sad) for SEM photographs, Momčilo Popović (Zemun) for providing sketches and Dragan Kaličanin for print preparation. 


\section{REFERENCES}

Адамовић, Ж. Р. (1975): Преглед врста Mantodea i Saltatoria нађених у СР Србији. Зборник радова о ентомофауни СР Србије, 1:9-84.

Brunner von Wattenwyl, C. (1882): Prodromus der Europäischen Orthopteren. Leipzig, W. Engelmann, XXXII+466 str.

Brunner von Wattenwyl, C. (1891): Additamenta zur Monographie der Phaneropteriden. - Verhandlungen der kaiserlich-königlichen zoologisch-botanischen Gesselschaft, Wien, 196 pp.

Chobanov, D. P., Grzywacz, B., Iorgu, I. S., Ciplak, B., Ilieva, M. B. \& Warchalowska - Sliwa, E.(2013): Review of the Balkan Isophya (Orthoptera: Phaneropteridae) with particular emphasis on the Isophya modesta group and remarks on the systematics of the genus based on morphological and acoustic data. Zootaxa. 3658(1): 001-081.

Harz, K. (1969): The Orthoptera of Europe I. The Hague: Series Entomologica 5. Dr. W. Junk B.V.

Heller, K.-G., Orci, K. M., Grein, G. \& Ingrisch, S. (2004): The Isophya species of central and western Europe (Orthoptera: Tettigonioidea, Phaneropteridae). Tijdschrift voor Entomologie, 147, 237-258.

Ingrisch, S. \& Pavićević, D. (2010): Seven new Tettigoniidae (Orthoptera) and a new Blattellidae (Blattodea) from the Durmitor area of Montenegro with notes on previously known taxa. Zootaxa. 2565: 1-41.

Панчић. J. (1883): Ортоптере у Србији, Гласник Српског ученог друштва, Београд, 172 стр.

Pavićević, D., Ivković, S. \& Horvat., L. (2014b): New and rare species of orthopteroid insects in the fauna of Serbia. Fauna Balkana, 3: 103-122.

Ramme, W. (1951): Zur Systematik, Faunistik und Biologie der Orthopterten von Südost - Europa und Vorderasien. Mitt. Zol. Mus. Berlin, 27: 1 431.

Szövényi, G. \& Szekeres, O. (2011) First record of Isophya costata in Serbia (Orthoptera: Phaneropteridae). Folia Entomologica Hungarica. 72:5-7.

\title{
ПРЕЛИМИНАРАН ОПИС НОВОГ РОДА ISOРНYА (ОRТНОРТЕRА: TETTIGONIOIDEA: PHANEROPTERIDAE) ИЗ СРБИЈЕ УЗ НАПОМЕНЕ О НЕКИМ ПОЗНАТИМ ВРСТАМА
}

\author{
Драган Павићевић
}

\section{Резиме}

Род Isophya у Европи има преко 45 врста а од тог броја у Србији је до сада било познато 6. То су следеће врсте: Isophya speciosa, I. modestior, I. obtusa, I. bureschi, I. clara и I. costata. Нова врста за фауну Србије је I. miksici са планине Бељанице. Са планине Радан описана је I. radmilae sp. n., ca планина Таре и Златибора је I. pancici sp. n. а из Београда I. clara orientalis ssp. n. Тиме је укупан број представника рода Isophya у Србији повећан на десет таксона, девет врста и једну подврсту. Нова врста са планине Радан, Isophya radmilae sp. n., je на основу спољашње морфологије блиска врсти $I$. modestior али се од ње јасно разликује другачијом песмом мужјака. Друга нова врста, I. pancici sp. n., са планине Таре и Златибора, такође је блиска врсти I. modestior, али се од ње, поред осталог, лако разликује другачијим положајем апикалног зубића на церку. Песма мужјака ове врсте није снимљена. Трећи таксон, I. clara orientalis ssp. n., описан из Београда (Миљаковац и Степин Луг), низом мањих морфолошких одлика разликује се од номинотипске подврсте, I. clara clara. Род Isophya, због велике морфолошке сличности међу врстама, са таксономске тачке гледишта, представља један од најтежих родова не само у оквиру фамилије Phaneropteridae којој припада, већ уопште међу ортоптерама. С обзиром да се ради о слабо вагилним животињицама, врло је вероватно да се међу врстама са ширим ареалом у ствари крије више различитих, криптичких врста. За што прецизнију детерминацију врста поменутог рода, поред класичне морфологије, данас се све више користи биоакустика и молекуларна генетика. 